Article

\title{
Properdin Modulates Complement Component Production in Stressed Human Primary Retinal Pigment Epithelium Cells
}

\author{
Nicole Schäfer ${ }^{1}$, Hannah N. Wolf ${ }^{1}$, Anne Enzbrenner ${ }^{1}$, Juliane Schikora ${ }^{1}$, \\ Maria Reichenthaler ${ }^{1}$, Volker Enzmann ${ }^{2,3,+} \mathbb{D}$ and Diana Pauly ${ }^{1, *},+\mathbb{D}$ \\ 1 Experimental Ophthalmology, Eye Clinic, University Hospital Regensburg, 93053 Regensburg, Germany; \\ Nicole.Schaefer@vkl.uni-regensburg.de (N.S.); Hannah.Wolf@stud.uni-regensburg.de (H.N.W.); \\ A.enzbrenner@googlemail.com (A.E.); Juliane.Schikora@stud.uni-regensburg.de (J.S.); \\ Maria.reichenthaler@googlemail.com (M.R.) \\ 2 Department of Ophthalmology, University Hospital of Bern, University of Bern, 3010 Bern, Switzerland; \\ Volker.Enzmann@insel.ch \\ 3 Department of Biomedical Research, University of Bern, 3010 Bern, Switzerland \\ * Correspondence: Diana.Pauly@ukr.de \\ + These authors share senior authorship.
}

Received: 21 July 2020; Accepted: 22 August 2020; Published: 26 August 2020

check for updates

\begin{abstract}
The retinal pigment epithelium (RPE) maintains visual function and preserves structural integrity of the retina. Chronic dysfunction of the RPE is associated with retinal degeneration, including age-related macular degeneration (AMD). The AMD pathogenesis includes both increased oxidative stress and complement dysregulation. Physiological sources of oxidative stress in the retina are well known, while complement sources and regulation are still under debate. Using human primary RPE (hpRPE) cells, we have established a model to investigate complement component expression on transcript and protein level in AMD-risk and non-risk hpRPE cells. We evaluated the effect of properdin, a complement stabilizer, on the hpRPE cell-dependent complement profile exposed to oxidative stress. hpRPE cells expressed complement components, receptors and regulators. Complement proteins were also stored and secreted by hpRPE cells. We associated AMD-risk single nucleotide polymorphisms with an increased secretion of complement factors D (CFD) and I (CFI). Furthermore, we detected hpRPE cell-associated complement activation products (C3a, C5a) independent of any extracellularly added complement system. Exogenous properdin increased the mRNA expression of CFI and CFD, but decreased levels of complement components $(C 1 Q, C 3)$, receptors $(C 3 A R, C 5 A R 1, C D 11 B)$ and inflammation-associated transcripts (NLRP3, IL1B) in hpRPE cells exposed to oxidative stress. This properdin effect was time-dependently counter regulated. In conclusion, our data unveiled a local, genotype-associated complement component production in hpRPE cells, regulated by exogenous properdin. The local complement production and activation via blood-independent mechanisms can be a new therapeutic target for AMD.
\end{abstract}

Keywords: retinal pigment epithelium; complement system; properdin; AMD-risk genotype; intracellular; cell-associated; inflammasome; oxidative stress; human

\section{Introduction}

As early as 2005, single nucleotide polymorphisms (SNP) in the complement factor H (CFH) gene were identified as genetic risk factors for age-related macular degeneration (AMD), the major cause of visual impairment in the Western world [1,2]. Today, it is known that at least eight of these AMD-risk factors reside in different genes encoding the complement system and enhanced complement deposition 
was observed in AMD-affected eyes [3-6]. However, we still miss a satisfactory answer how these SNPs or the complement system as a whole contributes to AMD.

The complement system is a pathway of the innate immune system, consisting of over 40 proteins, which are consecutively activated. Properdin, is the only known stabilizer of the complement system [7]. It binds to the central, activating protein complex of the cascade and prolongs its half-life by $5-10$ times. Next to stabilizing the central C3 convertase, properdin has also a potential role as a pattern recognition molecule activating the complement pathway. The whole complement cascade ensures a first line defense against pathogens and modified cells producing alarm molecules (anaphylatoxins), tagging cells/microorganisms (opsonins) or disrupting cell membranes (membrane attack complex) [8]. Additionally, non-canonical intracellular functions of complement components ("the complosome") have been described in T-cells, neutrophils, pancreatic $\beta$-cells and others [9-11]. Cell-associated or intracellular complement activity modulated cell metabolism, autophagy, survival, and differentiation in these different cell types [10,12-14]. However, so far the complement system has not been further investigated as a cell-dependent/autocrine pathway in relation to AMD so far.

Two major advanced stages of AMD can occur simultaneously in one patient or even in a single eye: Choroidal neovascularization (CNV) and geographic atrophy (GA) $[15,16]$. These completely different disease patterns cause either disruption or loss of the retinal pigment epithelium (RPE). Besides genetics, clinical data suggested additional external stimuli, for example oxidative stress or aging processes $[17,18]$, promoting different pathological outcomes in AMD. This needs to be taken into account investigating the role of complement in RPE and AMD.

The RPE forms the blood-retinal barrier, which separates the retina from the systemic circulation and the immune system [19]. The RPE acts as a regulatory, secretory epithelium supporting the retina. It locally secretes complement components as $\mathrm{C} 1 \mathrm{q}$, complement factor $\mathrm{B}$ (CFB), complement component 4 (C4), CFI, and CFH [20-23]. We and others showed that complement secretion is modified by external stress [20-26]. Additionally, generation of complement activation products, such as anaphylatoxins and opsonins, by healthy and stressed RPE cells independent of any external complement source is described $[21,24,26,27]$. Recently, it was reported, that endogenous CFH and anaphylatoxins contribute to transcriptional and metabolic homeostasis of RPE cells [28-30]. In RPE cells complement anaphylatoxins receptor signaling is involved in eye morphogenesis [31], sub-RPE deposits [32], pro-inflammatory RPE reaction [33-35], PI3/Akt-pathway activation [29], and stress-mediated lipid accumulation in RPE cells [36]. Together this indicates an involvement of autocrine complement reactivity in housekeeping mechanisms maintaining RPE physiology. However, it is not known in detail how this is controlled and how it contributes to retinal degeneration.

In the present study, we tested whether human primary RPE (hPRPE) cells produce and activate complement components in dependence of their genotype and exogenous properdin stress. We demonstrated that hpRPE cells positive for a homozygous AMD-risk SNP within complement genes secreted more complement proteins than non-carriers. Thereby, we supposed that the complement stabilizer properdin modifies the local complement homeostasis in stressed hpRPE cells. We described that hpRPE cell-dependent complement levels were time-dependently changed by oxidative stress and properdin addition.

\section{Materials and Methods}

\subsection{Cultivation and Treatment of $h p R P E$}

The research complies with the human research act (HRA) stating that small quantities of bodily substances removed in the course of transplantation may be anonymized for research purposes without consent (HRA chapter 5, paragraph 38, Switzerland). hpRPE were prepared from left and right eyes of 15 anonymized donors (Table 1) as previously described [37,38]. Briefly, hpRPE cells were harvested from the eyecup after enzymatic digestion and centrifuged with $259 \times \mathrm{g}$ at $4{ }^{\circ} \mathrm{C}$ for 5 min. hpRPE cells were cultivated in Dulbecco's modified Eagle's medium/Nutrient Mixture F-12 
(DMEM/F 12 GlutaMax, Thermo Fisher Scientific, Dreieich, Germany, \#31331-028) containing 5\% fetal bovine serum (FBS, Thermo Fisher Scientific, \#10500-064), 1\% Penicillin-Streptomycin (Thermo Fisher Scientific, \#15070-063), 1\% N1 Medium Supplement (Merck, Darmstadt, Germany, \#N6530), $10 \mathrm{mM}$ MEM non-essential amino acids (Thermo Fisher Scientific, \#11140-035), 0.25 mg/mL Taurine (Merck, \#T0625), 4.5 mg/mL Glucose solution (Thermo Fisher Scientific, \#G524940-01), 0.013 ng/mL Triiodothyronine (Merck, \#T2877), $0.02 \mu \mathrm{g} / \mathrm{mL}$ Hydrocortisone (Merck, \#H0888), 20 ng/mL human basic growth factor (hbFGF, R\&D Systems, Minneapolis, MN, USA, \#13256029) and $1 \mathrm{mg} / \mathrm{mL}$ human epidermal growth factor (hEGF, Thermo Fisher Scientific, \#PHG0311) in laminin-coated Transwell ${ }^{\circledR}$ inserts under standard conditions $\left(37^{\circ} \mathrm{C}, 5 \% \mathrm{CO}_{2}, 80 \%\right.$ humidity).

Table 1. Human primary retinal pigment epithelium (hpRPE) cell genotyping and experimental assignment in this study.

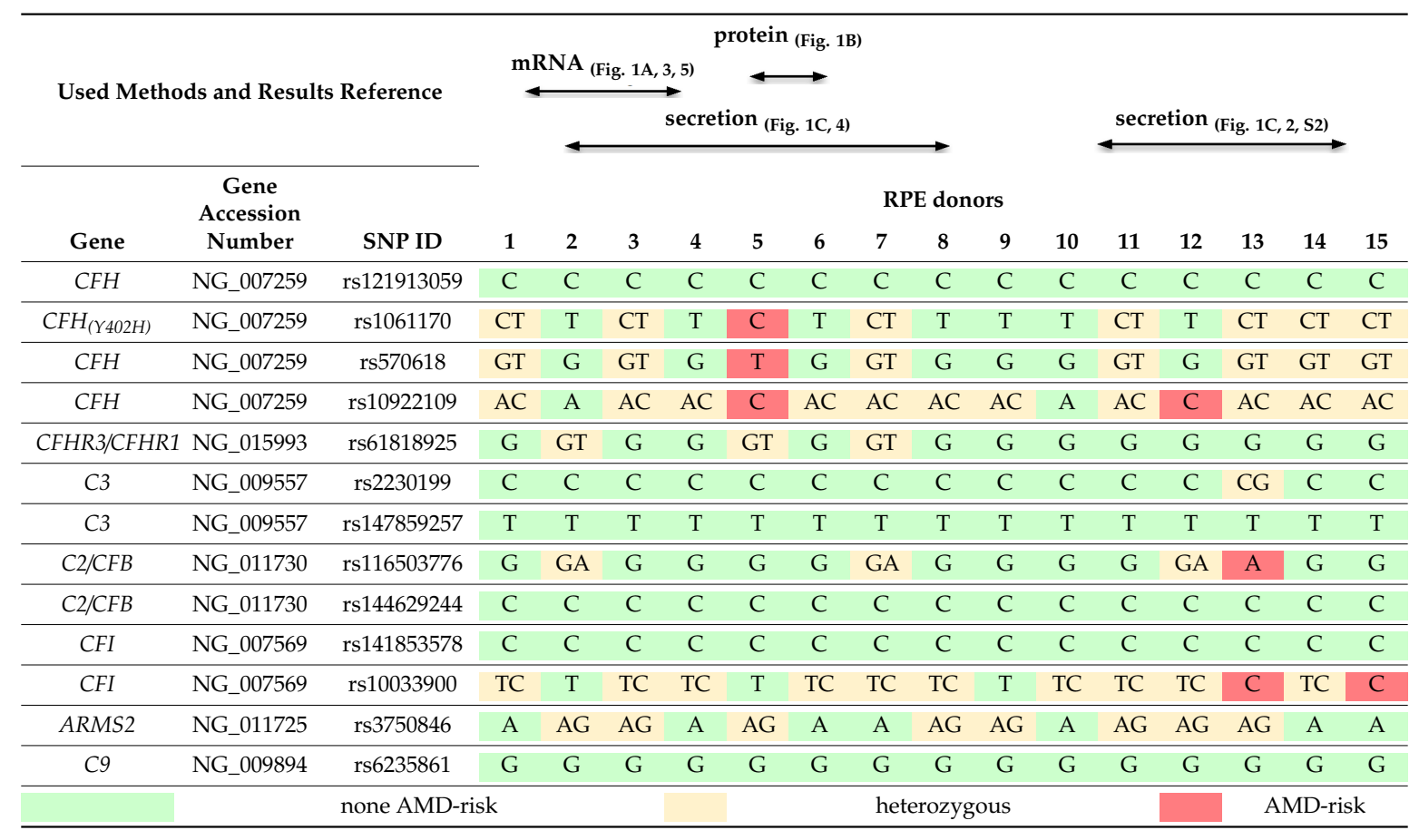

Before treatment, FBS concentration was reduced to $0 \%$ within 3 days $(5 \%-2.5 \%-1.25 \%$, respectively). hpRPE cells were apically treated either with $0.5 \mathrm{mM} \mathrm{H} \mathrm{O}_{2}$, or $0.5 \mathrm{mM} \mathrm{H}_{2} \mathrm{O}_{2}$ and $50 \mu \mathrm{g} / \mathrm{mL}$ properdin (Complement Technology, Tyler, TC, USA, \#A139) for 4, 10, or 24 h. Supernatants (apical and basal) were taken before and after treatment, subsequently frozen in liquid nitrogen and stored at $-80^{\circ} \mathrm{C}$.

\section{2. hpRPE Genotyping}

DNA was isolated from sclera slices of the respective donor eyes using ReliaPrep ${ }^{\mathrm{TM}}$ FFPE gDNA Miniprep System (Promega, Mannheim, Germany, \#A2351). PCR for amplification of DNA sequences containing relevant AMD-associated complement SNPs was performed using in-house generated primers (Table S1) and the following cycle steps, according to the MIQE guidelines [39]: denaturation $\left(95^{\circ} \mathrm{C}, 1 \mathrm{~min}\right)$, annealing $\left(60^{\circ} \mathrm{C}, 1 \mathrm{~min}\right)$, elongation $\left(72^{\circ} \mathrm{C}, 1 \mathrm{~min}\right), 33$ cycles. Afterwards, DNA-sequencing was performed by GeneArt (Thermo Fisher Scientific) using either forward or reverse in-house primers, respectively (Table S1).

\section{3. $R T-q P C R$ and $P C R$}

mRNA was isolated using the NucleoSpin ${ }^{\circledR}$ RNA kit (Macherey-Nagel, Düren, Germany, \#740955) and transcribed into cDNA with the QuantiTect ${ }^{\circledR}$ Reverse Transcription Kit (Qiagen, Hilden, Germany, 
\#205313). Transcripts of complement components, regulators, receptors and inflammation-associated markers were analyzed (i) by PCR (as described in Section 2.2.) and subsequent $2 \%$ agarosegel separation for cDNA fragment visualization, or (ii) by qPCR using Rotor-Gene SYBR ${ }^{\circledR}$ Green PCR Kit (Qiagen) in a Rotor Gene Q 2plex cycler (Qiagen) either with QuantiTect Primer Assays (Qiagen, Table S2), or in-house designed primers for IL1B, VIM and SMA1 (Metabion, Planedd, Germany, Table S1). Data were normalized to the housekeeper GAPDH expression and fold change was calculates using 2(-Delta Delta C(T)) method [40]. Data are visualized on a linear scale using log2-transformed scores [41].

\subsection{Multiplex Complement Secretion Assay}

Complement components in the cellular supernatants after 11-14 days of cultivation were quantified using the MILLIPLEX MAP Human Complement Panel (Merck, \#HCMP1MAG-19K, \#HCMP2MAG-19K) in accordance to the manufacturer's protocol. The read out of the multiplex assay was performed in a Magpix instrument (Luminex, Austin, TX, USA).

\subsection{Western Blot}

Lysates of hpRPE cells were generated using RIPA buffer (Sigma-Aldrich, Munich, Germany, \#R0278) with protease and phosphatase inhibitors (1:100, Sigma-Aldrich, \#P8340). Samples were dissolved in reducing Laemmli sample buffer, denatured $\left(95^{\circ} \mathrm{C}, 10 \mathrm{~min}\right)$ and separated in a $12 \%$ SDS-PAGE and transferred on to an activated PVDF membrane using a wet blotting system. Membranes were blocked ( $1 \mathrm{~h}, 5 \%$ bovine serum albumin (BSA)/PBS-T) and incubated with the primary antibodies (overnight, 5\% BSA/PBS-T): Rabbit anti-GAPDH-HRP (1:1000, Cell Signaling Technology, Beverly, MA, USA, \#3683), mouse anti-C3 (1:100, Progen, Heidelberg, Germany, \#61019), goat anti-CFI (1:250, Quidel, San Diego, CA, USA, \#A313), mouse anti-C3a (1:50, Hycult, Uden, Netherlands, \#HM2074) and mouse anti-C5a-biotin (1:250, Biozol, Eching, Germany, \#BLD-518306). Peroxdiase-conjugated anti-species antibodies were used for detection (1 h, PBS-T): goat anti-mouse (1:5000, Jackson ImmunoResearch, West Grove, PA, USA, \#115-035-164), rabbit anti-goat (1:5000, Jackson ImmunoResearch, \#305-035-003). Visualization was performed by WesternSure PREMIUM Chemiluminescent Substrate (LI-COR, Bad Homburg, Germany, \#926-95000) in a Fluor Chem FC2 Imaging System (Alpha Innotech, San Leandro, CA, USA).

\subsection{Immunohistochemistry}

Immunostaining was performed as described previously [22]. PBS-washed, paraformaldehyde-fixated (4\%, 20 min; Merck, \# 100496) hpRPE cells were blocked 3\% BSA (Carl Roth, Karlsruhe, Germany, \#8076/ PBS-T, 1 h). Antigens were detected using primary antibodies anti-RPE65 (1:200; Abcam, Cambridge, UK \#ab13826) or anti-bestrophin (1:200; Novus Biologicals, Littleton, CO, USA \#NB300-164), visualized with goat anti-mouse ALEXA Fluor 594 (1:500; Thermo Fisher Scientific, \#A32742) and complemented with nuclei staining (DAPI; Vector Labs, Burlingame, CA, USA, \#H-2000,). Cells were covered with fluorescence mounting medium (Agilent, Boeblingen, Germany, \#S302380-2).

\subsection{Statistics}

Statistical analysis was performed using GraphPad Prism 7 (GraphPad Software Inc, San Diego, CA, USA). We estimated a normal Gaussian distribution. Significance levels were determined by the parametric, unpaired $t$-test. Welch's test was used to correct for unequal sample distribution variance. All data are expressed as mean \pm standard deviation (SD) unless stated otherwise. Detailed information about specific n-values, implemented statistical tests and coding of significance levels are provided in the respective figures and figure legends. 


\section{Results}

RPE cells are capable of producing cell-derived complement components as we showed recently [22,42]. In the present study we assume that an externally added complement regulator, properdin, can modulate stress-dependent RPE cell-derived complement components.

\subsection{Human Primary RPE Cells as a Model System in Cell Culture}

We investigated human primary RPE (hPRPE) cells, isolated and cultivated from 15 different donor eyes (Table 1). Studied hpRPE cells were vital and pigmented as well as positive for the RPE markers RPE65 and bestrophin (Figure S1A-G). Pigmentation of the hpRPE cells was stable from 4 to 14 days of cultivation (after removal of non-adherent cells at day 2).

Ex vivo cultivation of hpRPE of both eyes resulted in a maximum of 6 transwell filters with a growth area of $1.12 \mathrm{~cm}^{2}$ from each donor. This limited the study and not all investigations could be performed with the hpRPE cells from the same donor. An overview of the used cell preparations and experiments is given in Table 1.

\section{2. hpRPE Cells Produce Complement Components}

All tested hpRPE cells were positive for transcripts of complement components $C 1 Q, C 3, C 4 A$, $C 4 B, C 5, C F B$, and $C F D$, as well as complement regulators $C F I, C F H$, properdin (CFP), CD46, and CD59 (Figure 1A). hpRPE cells expressed also complement receptors for complement activation products like the anaphylatoxin receptors $C 3 A R$ and $C 5 A R 1$ as well as the subunit $C D 11 B$ of complement receptor 3, which interacts with the C3 cleavage products (iC3b, C3d, C3dg) upon activation (Figure 1A).

hpRPE cells produced complement proteins as C3 and CFI shown by Western blot (Figure 1B). This raised the question, if complement receptors of hpRPE cells could be modulated in an autocrine signaling pathway if complement activation products are generated by these cells. Analyzing hpRPE cell lysates in Western blot, we found hpRPE cell-derived complement activation products C3a, C5a and further C3 cleavage products (C3d, C3dg) in untreated hpRPE cells independent from any external complement sources, indicating a possible autocrine cleavage and function of hpRPE cell-derived activated complement components (Figure 1B and Figure S2 ).

We also determined secreted complement components in the cell culture supernatants of hpRPE preparations from both eyes 11-14 days after isolation (Figure 1C). Thereby, we detected C3, C3b, C4, $\mathrm{CFB}, \mathrm{CFD}$ and the regulators CFI as well as CFH in the supernatants (Figure 1C). C1q, C5 and the complement activation products $\mathrm{C} 4 \mathrm{~b}$ and $\mathrm{C} 5 \mathrm{a}$ were either not secreted or below the assay detection limits (Figure 1C). We also identified differences of complement secretion levels between hpRPE cell preparations of the left and right eye (Figure S3). However, we cannot judge the influence of retinal phenotype and cell preparation differences. Apical and basal complement secretion levels were comparable (Figure S3), but due to low cell numbers and reduced cell division of hpRPE a confluent monolayer was not always observable. Furthermore, we cannot exclude passive diffusion of the complement components secreted apically and basally through the membrane filter (Figure S3). 
A
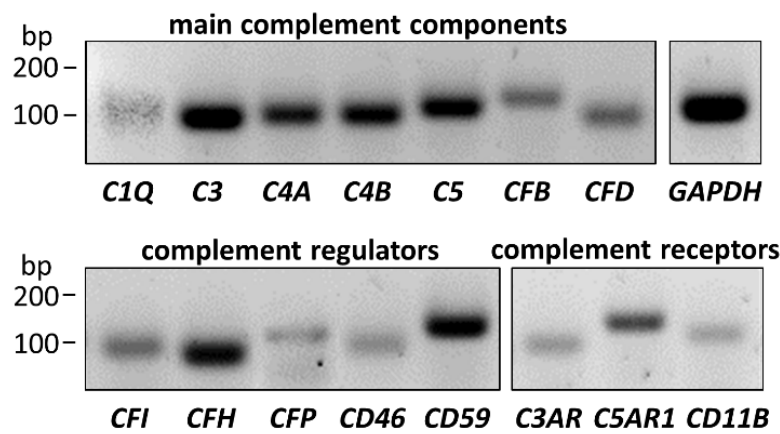

CFI CFH CFP CD46 CD59 C3AR C5AR1 CD11B

B

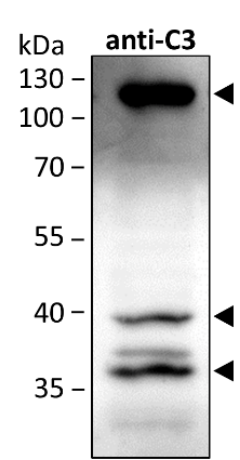

anti-

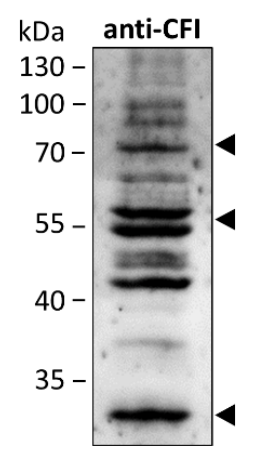

C

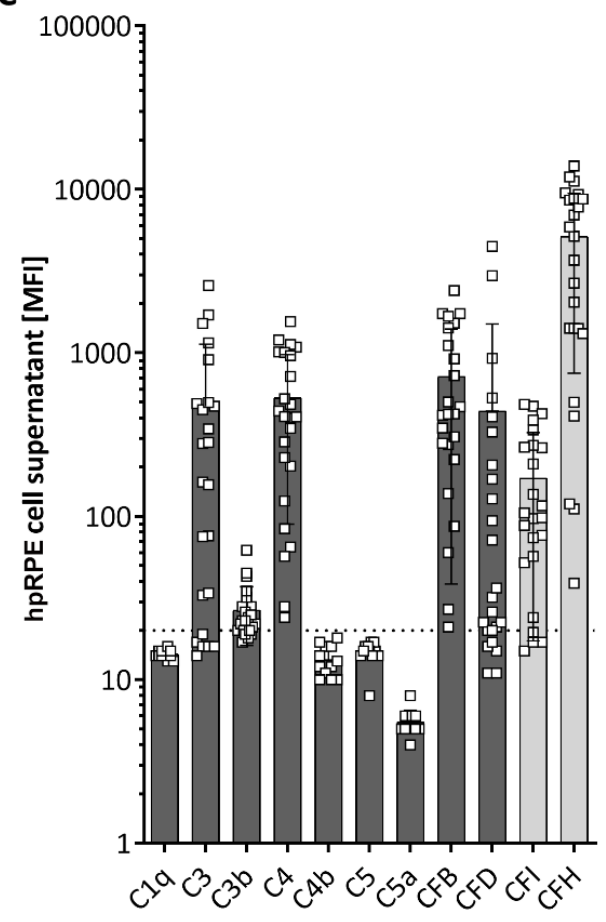

Figure 1. hpRPE cells express and secrete complement components. (A) mRNA expression of main complement components of the classical $(C 1 Q)$, central (C3) classical/lectin (C4A, C4B), terminal (C5) and alternative (CFB, $C F D)$ complement pathway was detected in hpRPE cells. hpRPE cells expressed also mRNA of soluble (CFI, CFH, CFP) and membrane bound (CD46, CD59) complement regulators, and transcripts of complement receptors: anaphylatoxin receptors (C3AR, C5AR1), opsonin receptor CR3 subunit $(C D 11 B)$. Shown expression data of donor 1 are representative for mRNA experiments in hpRPE cells of donors 1-4 (Table 1). (B) Activation products of the central complement component C3 [(blot left, arrows) C3b (115 kDa), C3dg (39 kDa) and C3d (35 kDa)] were detected in hpRPE. Multiple bands were identified in hpRPE cells using an anti-complement regulator CFI antibody (blot center, arrows for full CFI (80 kDa) and two CFI disulfide linked chains (50 kDa, $30 \mathrm{kDa})$ ). Anaphylatoxins C3a and C5a (blot right) were found in cell lysates of hpRPE cells. Examples of whole blots are depicted in (B) for donor 5 (C5a) and donor 6 (C3, C3a, CFI). (C) hpRPE cells secrete C3, C4, CFB, CFD and the regulators $\mathrm{CFI}$ as well as $\mathrm{CFH}$ into the cell culture supernatant (pooled data of two eyes, apical and basal supernatant are shown, details for hpRPE cells of donors 11-16 are presented in Figure S3). Mean with standard deviation is shown. Dotted line depicts blank control. MFI-mean fluorescence intensity.

\subsection{AMD-Risk SNPs in Complement Genes Increase hpRPE Cell-Dependent Complement Secretion}

SNPs within genes of the complement cascade were previously associated with the risk of retinal degeneration and changed retinal/RPE physiology [4,43,44]. We analyzed 13 complement-associated risk SNPs in the donor tissues to evaluate the effect of these SNPs on hpRPE cell-derived complement secretion. We found 4 of 15 donors positive for 1-3 homozygous AMD-risk SNPs either in the $C F H$, C2/CFB or CFI gene loci and all donors were positive for 1-5 heterozygous AMD-risk SNPs (Table 1).

Furthermore, we compared complement secretion levels of hpRPE cells positive for at least one homozygous AMD-risk SNPs SNP (donors 12, 13, 15) and non-homozygous AMD-risk SNP hpRPE cells (donors 10, 11, 14) (Table 1, Figure 2). Thereby, significantly higher CFD and CFI levels in supernatants of hpRPE cells with the AMD-associated risk SNPs in complement genes were found (Figure 2A,B). A comparable tendency was also observed for complement regulators $\mathrm{CFH}$ and the central complement component $\mathrm{C} 3$, which were increased in supernatants of hpRPE with the AMD-risk genotypes after 14 days of cultivation compared to non-risk cells (Figure 2C,D). Only the secretion of components of the alternative pathway was affected by AMD-risk SNPs in complement genes 
under the described experimental conditions. However, we cannot definitely state that the hpRPE culture always resulted in the same cell numbers on the transwell filters investigated (even the same preparation protocol was used).
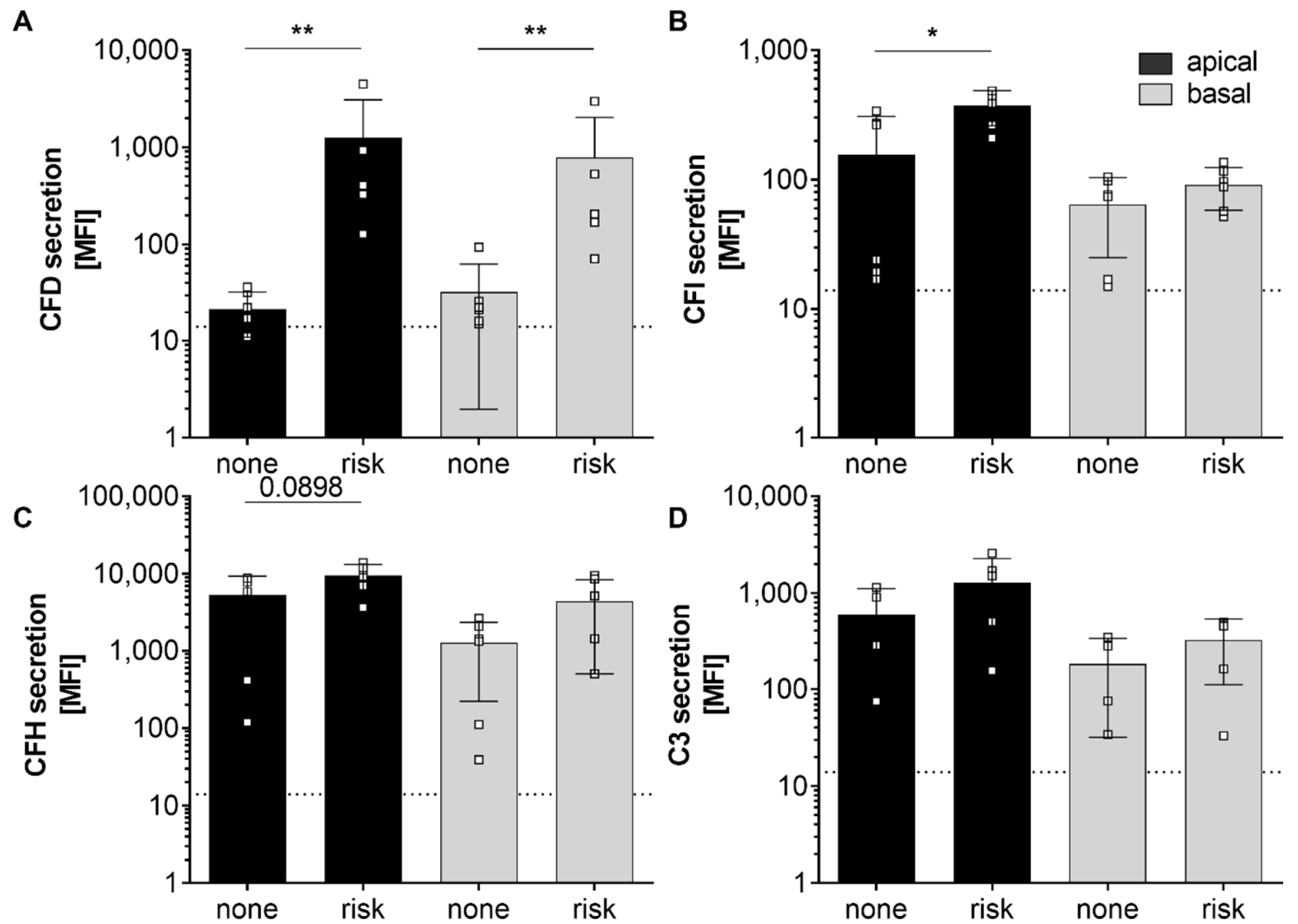

Figure 2. Secretion of alternative complement pathway components was increased in hpRPE cells positive for homozygous age-related macular degeneration (AMD)-risk single nucleotide polymorphisms (SNPs) (risk; donors 12, 13, 15). Significant higher levels of secreted (A) complement factors D (CFD), (B) complement factors I (CFI) and in tendency higher (C) complement factor H (CFH) and (D) C3 secretion levels were detected in apical (black) and basal (grey) supernatants of hpRPE cells with homozygous AMD-risk SNPs (risk; donors 12, 13, 15) compared to hpRPE cells without a homozygous AMD-risk SNP (none; donors 10, 11, 14) in complement genes (Table 1). Mean with standard deviation is shown. ${ }^{*} p<0.05,{ }^{* *} p<0.01$ unpaired $t$-test with Welch's correction. Dotted line depicts blank control. MFI-mean fluorescence intensity.

\subsection{Complement Regulator Properdin Increased Expression of Complement Proteases in Stressed hpRPE Cells}

We showed recently that oxidative stress increased the expression of complement regulator properdin in RPE cells [22]. In the present study, we investigated the effect of externally added properdin on stressed hpRPE cells. hpRPE cells were treated either with $\mathrm{H}_{2} \mathrm{O}_{2}$ alone or with combined $\mathrm{H}_{2} \mathrm{O}_{2}$ and properdin. Transcript levels of markers for epithelial-mesenchymal transition (EMT), complement components, regulators and receptors were compared between these treatment groups (Figure 3 and Figure S1). After $4 \mathrm{~h}$ of properdin treatment, hpRPE cells showed a tendency of increased EMT markers (Figure S1). Simultaneously, transcripts for complement proteases CFD and CFI were significantly upregulated in hpRPE cells (Figure 3A), while other complement components, which are involved in the general complement cascade $(C 1 Q, C 3)$, and complement receptors $(C 3 A R$, $C 5 A R 1, C D 11 B$ ) were downregulated (Figure 3A). This effect slightly differed in the four tested hpRPE preparations of donors 1-4 pooled in herein, but a genotype-dependent reaction was not observable due to limitations of the cohort size. All tested hpRPE preparations were negative for a homozygous 
AMD-risk SNP within complement genes (Table 1). Properdin treatment of stressed cells did not change the expression levels of $C 4, C D 59, C D 46$, and CFP (data not shown).

A

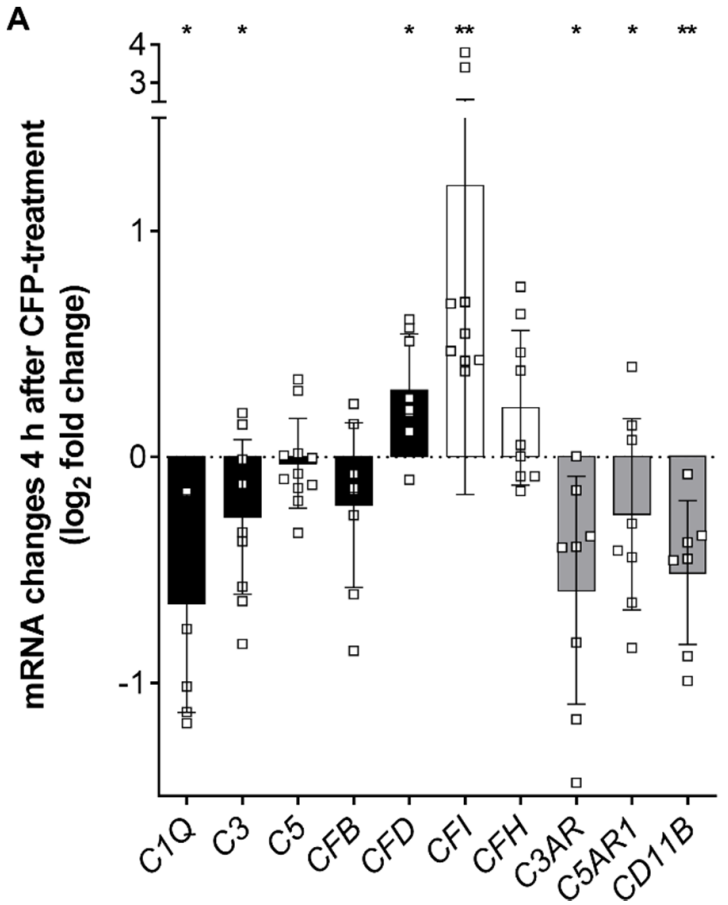

B

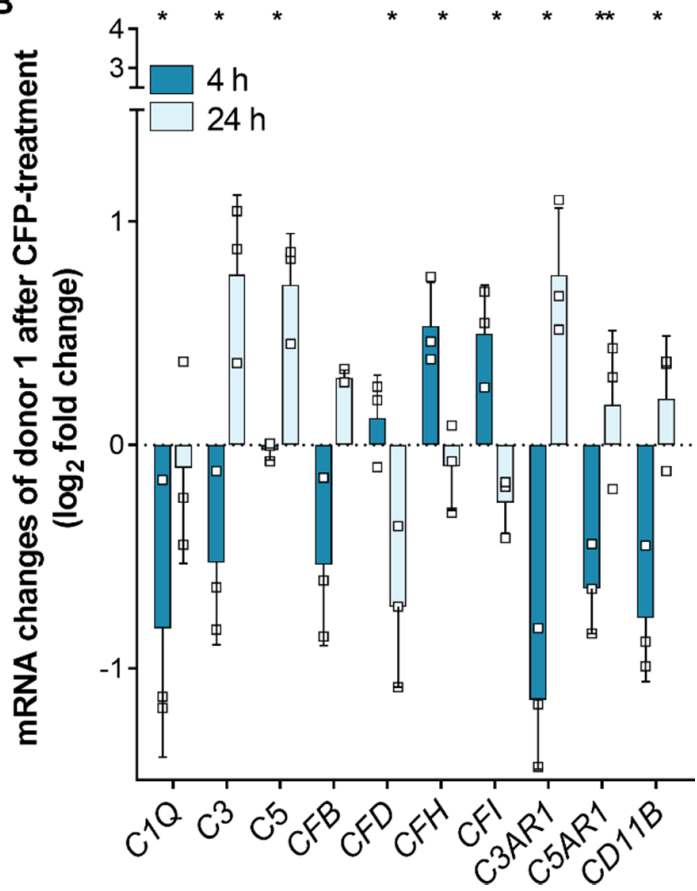

Figure 3. Complement regulator properdin changed complement mRNA expression in stressed hpRPE cells. (A) $\mathrm{H}_{2} \mathrm{O}_{2}$ stressed hpRPE cells were treated with properdin (CFP) for $4 \mathrm{~h}$. mRNA expression of main complement components $C 1 Q, C 3, C 5$, and $C F B$ (black) as well as complement receptors C3AR, C5AR1, and CD11B (grey) was decreased in comparison to stressed cells (dotted line). CFD (black) and complement regulators CFI and CFH (white) mRNA expression was increased in stressed, properdin-treated cells compared to stressed cells only. Data from donors 1-4 are presented. Mean with standard deviation is shown. ${ }^{*} p<0.05,{ }^{* *} p<0.01$ unpaired $t$-test with Welch's correction of stressed versus stressed, properdin-treated cells. (B) $\mathrm{H}_{2} \mathrm{O}_{2}$ stressed hpRPE cells of donor 1 were treated with properdin for $4 \mathrm{~h}$ (dark blue) or $24 \mathrm{~h}$ (light blue). mRNA Expression of complement components and receptors was reversed after $24 \mathrm{~h}$ compared to $4 \mathrm{~h}$. Mean with standard deviation is shown. ${ }^{*} p<$ $0.05,{ }^{* *} p<0.01$ unpaired $t$-test with Welch's correction of $4 \mathrm{~h}$ versus $24 \mathrm{~h}$ properdin treatment.

hpRPE cells of donor 1 were used to compare the early $(4 \mathrm{~h})$ and late $(24 \mathrm{~h})$ effect of external properdin on transcription levels (Figure 3B). We found time-dependent differences of complement expression in properdin-treated cells for all investigated transcripts. Transcription tendencies detected after $4 \mathrm{~h}$ were always reversed after $24 \mathrm{~h}$. For example, complement proteases CFD and CFI were decreased and mRNA of complement receptors C3AR, C5AR1, and CD11B were increased after $24 \mathrm{~h}$ (Figure 3B).

In summary, our expression data suggested an early anti-inflammatory and a late pro-inflammatory transcriptional response of stressed hpRPE cells upon properdin treatment.

Consistent with the transcription results secretion of complement components CFD, CFI, and $\mathrm{CFH}$ was time-dependently changed in stressed, properdin-treated hpRPE cells compared to stressed cells (Figure 4). CFD levels in the apical supernatant were increased $4 \mathrm{~h}$ after properdin treatment and declined over time. This was in accordance with the mRNA transcription analyses (Figure 3). In contrast to the transcription results, where we described an early increase of CFI and CFH mRNA, the protein levels of CFI and CFH were rather reduced in the supernatant of properdin-treated hpRPE cells (Figure 4). This suggested an intracellular accumulation of these proteins following properdin interaction as described previously for stressed ARPE-19 cells [22]. C4 and CFB secretion 
was not significantly changed by properdin addition (Figure 4). C3 secretion could not be reliably determined, as the added properdin resulted in unspecific signals in the used commercial multiplex complement assay.

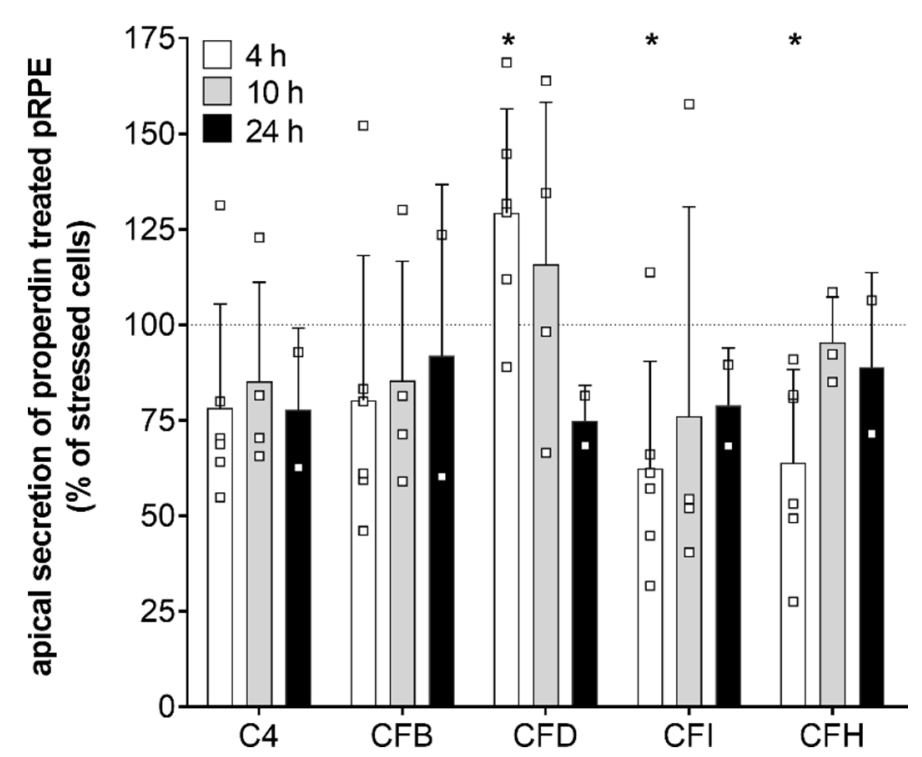

Figure 4. Complement protein secretion was modulated in stressed hpRPE cells by properdin. Complement protein secretion into the apical supernatant $4 \mathrm{~h}$ (white), $10 \mathrm{~h}$ (grey) and $24 \mathrm{~h}$ (black) after properdin treatment of $\mathrm{H}_{2} \mathrm{O}_{2}$ stressed hpRPE is shown as percentage of the secretion level of stressed, non-properdin treated cells (dotted line). We observed a time-dependent change in CFD levels (significantly increased after $4 \mathrm{~h}$ ) in apical supernatants of stressed properdin-treated hpRPE cells. Decreased concentrations of complement regulators $\mathrm{CFI}$ and $\mathrm{CFH}$ were detected after $4 \mathrm{~h}$ of properdin treatment. Shown are data of donors 2, 4, and 8 for $4 \mathrm{~h}$; donors 3, 5, and 6 for $10 \mathrm{~h}$; donor 1 for $24 \mathrm{~h}$. Mean with standard deviation is shown. ${ }^{*} p<0.05,{ }^{* *} p<0.01 t$-test with Welch's correction of stressed hPRPE versus stressed, properdin-treated hpRPE.

\subsection{Inflammasome-Associated Transcription Levels were Reduced by Properdin in Stressed hpRPE Cells}

Recently, we showed an increase of inflammasome activation following oxidative stress in ARPE-19 cells [22]. To answer the question how the complement regulator properdin acts on inflammasome-associated mRNA expression in stressed RPE cells, we investigated NLRP3 and IL1B transcripts in properdin-treated and non-treated stressed hPRPE cells (Figure 5). NLRP3 and IL1B expression was decreased after $4 \mathrm{~h}$ in properdin-treated cells compared to only $\mathrm{H}_{2} \mathrm{O}_{2}$-stressed cells (Figure 5B). This confirmed the suggested early anti-inflammatory effect of properdin on $\mathrm{H}_{2} \mathrm{O}_{2}$-stressed hpRPE cells (Figure 3A). After $24 \mathrm{~h} \mathrm{NLRP3} \mathrm{transcripts} \mathrm{were} \mathrm{still} \mathrm{reduced,} \mathrm{but} \mathrm{IL1B} \mathrm{were} \mathrm{counter}$ regulated in comparison to $4 \mathrm{~h}$ with increased IL1B levels (Figure 5C). 
A
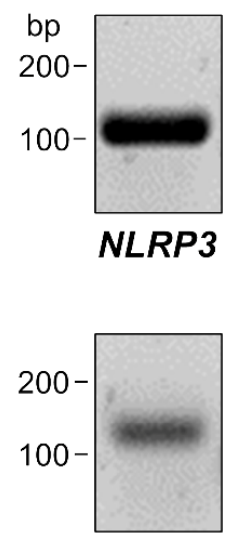

IL1B

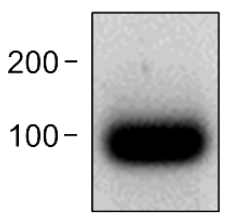

GAPDH
B

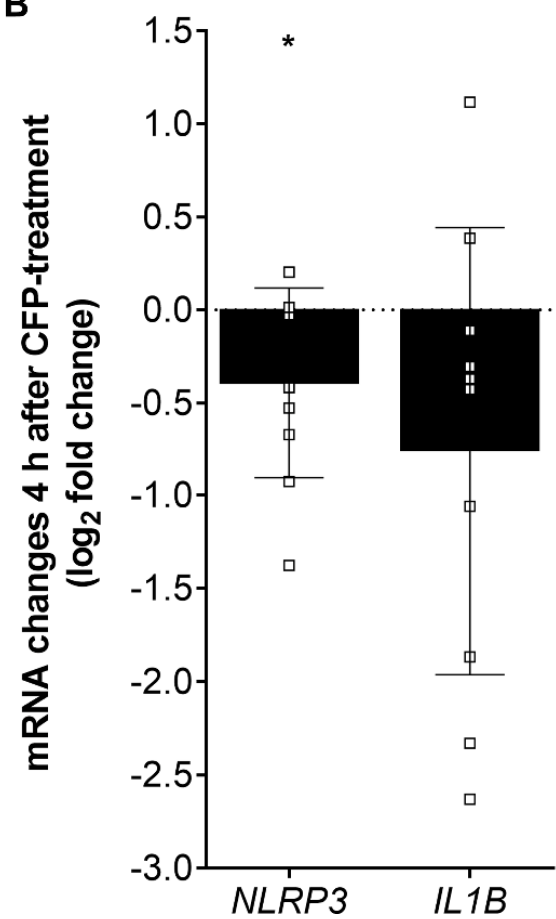

C

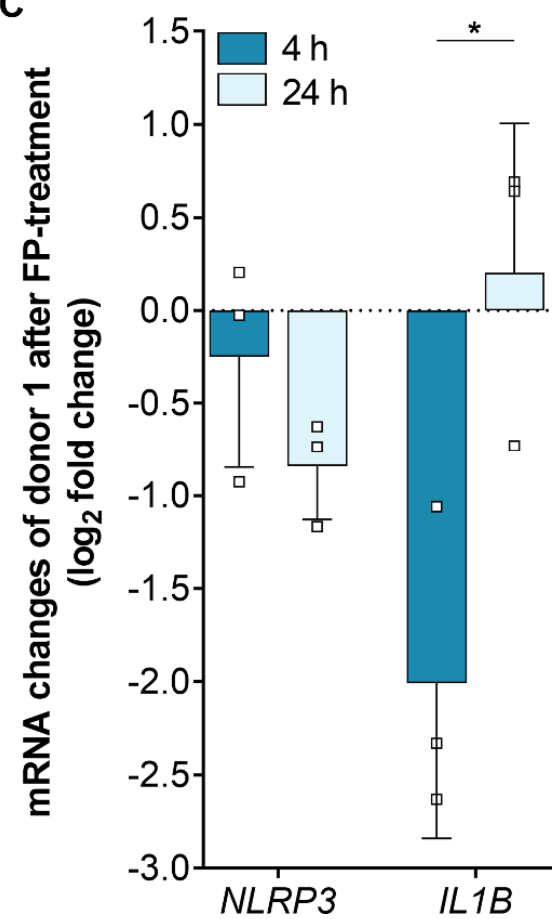

Figure 5. Inflammasome-associated mRNA transcripts were differentially expressed in stressed, properdin-treated hpRPE cells. (A) Inflammasome NLRP3 and pro-inflammatory cytokine IL1B mRNA was detected in hpRPE cells. Shown expression data of donor 1 are representative for mRNA experiments in hpRPE cells of donors 1-4 (Table 1). (B) Properdin treatment of $\mathrm{H}_{2} \mathrm{O}_{2}$-stressed hpRPE cells showed a significant reduced expression of NLRP3 and IL1B after $4 \mathrm{~h}$. Data from donors $1-4$ are presented. (C) $\mathrm{H}_{2} \mathrm{O}_{2}$-stressed hpRPE cells of donor 1 were treated with properdin for $4 \mathrm{~h}$ (dark blue) or $24 \mathrm{~h}$ (light blue). Reduced NLRP3 mRNA expression was accelerated over time and IL1B transcripts were significantly increased after $24 \mathrm{~h}$ compared to $4 \mathrm{~h}$ properdin incubation. Mean with standard deviation is shown. ${ }^{*} p<0.05,{ }^{* *} p<0.01$ unpaired $t$-test with Welch's correction of $4 \mathrm{~h}$ versus $24 \mathrm{~h}$ properdin treatment.

\section{Discussion}

AMD is a multifactorial pathological process in the retina resulting from alteration of the RPE. Chronic inflammatory changes in the RPE can lead to blood-retinal barrier breakdown and disease progression. Thereby, the innate immunity including the complement system plays a pivotal role. Our study demonstrated that components of the complement system, a part of the innate immune system are produced and secreted by RPE cells. The local complement quantity and activity was modulated by external stress affecting the RPE and contributing to a disturbed blood-retinal barrier.

\subsection{Biological Relevance of $h p R P E$ In Vitro Experiments}

RPE cells are differentiated and polarized cells, which form a monolayer and are part of the blood-retinal barrier between the photoreceptors and Bruch's membrane. The main functions of the RPE are: (i) Absorption of light and protection against photo-oxidation, (ii) secretion of immune modulators and growth factors as well as (iii) phagocytosis and recycling of shed photoreceptor [19]. These activities can be altered under non-physiological conditions. In this study, we used hpRPE cells from human donors in order to assure as much in vivo-like RPE cell characteristics as possible in our in vitro experiments. Different genotypes, environmental influences and in vivo differentiation had an impact on the variability and biological relevance of our results. We investigated hpRPE cells from the right and the left eye of 15 different donors, which reflected the RPE phenotype in the human eye [45]. This attached high importance to our results compared to results obtained from immortal, 
manipulated cell lines [46-48] (RPE in vitro systems were excellently reviewed in [19]). Optimal culture conditions resulted in physiological cell morphology and pigmentation of the ex vivo supplied cells [45]. Pigmentation of the RPE cells was a marker for differentiation, not often detected in cultured human RPE cell lines [49].

\section{2. hpRPE as a Source for Complement Components in the Eye}

Previous work identified the RPE as one of the major sources of complement transcripts in the mouse retina $[42,50]$. Here, we presented for the first time a comprehensive description of transcribed complement components (C1Q, C3, C4, C5, CFB, CFD), regulators (CFI, CFH, CFP, CD46, CD59) and receptors $(C 3 A R, C 5 A R 1, C D 11 B)$ in cultivated hpRPE cells. In accordance with our results $C 3, C F H$, and complement receptor $C 5 A R$ have already been shown to be expressed in the immortalized retinal pigment epithelial cell line ARPE-19 and in primary RPE cells [22,35,51]. RPE cells derived from induced pluripotent stem cells (iPSC) express mRNA for complement activators $C 3, C 5, C F B$, and complement inhibitors CFH, CFI, CD46, CD55, CD59, CLUSTERIN, and VITRONECTIN [23]. Single cell transcriptomic analysis in human organoids also showed $C F H, C 3$, and $C 2$ expression in RPE cells [52].

Similar to hpRPE, non-liver dependent complement gene expression was also described for intestinal epithelial cells, podocytes and other cell types [42,53,54].

In addition to complement transcripts, we also detected complement components $\mathrm{C} 3, \mathrm{C} 3 \mathrm{~b}, \mathrm{C} 4$, $\mathrm{CFB}, \mathrm{CFD}$ as well as complement regulators $\mathrm{CFI}$ and CFH in supernatants of hpRPE cells independent of any external complement sources. This was in line with previously published data for post-confluent ARPE-19 cells which secreted C3, C3a, C4bp, CFI, and CFH [20-22] and iPSC-derived RPE cells that secreted CFB $[23,26]$. C3 was previously also found in supernatants of primary mouse RPE cells [50]. Therewith, our and other results suggest a local RPE cell-dependent source of the complement components independent from liver-derived complement proteins in the eye.

hpRPE cell-dependent complement secretion was regulated by environmental, external stimuli. We documented variable complement levels in supernatants comparing secretion of left and right eye hpRPE of the same donor. In contrast to inherited eye diseases, where often both eyes are affected to a similar extent, acquired vision loss can occur in different degrees in the left and right eye. For AMD it is known that the disease progression can be dissimilar between both eyes $[55,56]$. Our data support this monocular specific disease progression also on the level of hpRPE cell-dependent complement secretion.

\subsection{AMD-Risk SNPs in Complement Genes Enhanced hpRPE Cell-Dependent Complement Secretion}

RPE dysfunction in AMD is associated with SNPs in complement system genes. An international AMD-genome wide association study listed six complement gene loci as top priority AMD-relevant risk candidates based on biological and statistical evidence $[4,57,58]$. Nevertheless, detailed studies of how precisely certain AMD-risk genotypes modify complement function and protein expression are still lacking.

Here, we found that these SNPs within the complement genes modulate local complement secretion. hpRPE obtained from donors positive for at least one homozygous complement risk SNP secreted higher levels of complement components than hpRPE cells heterozygous for the complement-associated AMD-risk SNPs. The increase was significant for alternative complement pathway components CFD/ $\mathrm{CFI}$ and a tendency was observed for $\mathrm{CFH} / \mathrm{C} 3$. Related research showed that AMD-risk SNP enhances complement activity in the RPE and the retina. Higher levels of C5a in Bruch's membrane and increased membrane attack complex deposition in eyes homozygous for the high-risk CFH genotype $\mathrm{Y} 402 \mathrm{H}$ were identified [43,44]. Complement dysregulation was also described for a homozygous risk-SNP in the ARMS2 gene [59]. In contrast, blood-derived CFI was reduced in AMD patients with a CFI SNP compared to patients without the SNP [60].

At least two mechanistic models are possible how genetic polymorphism in genes of the complement system could modify the ability of hpRPE cells to secrete components: (i) Polymorphism 
within a gene or in a regulatory region near a gene itself could results in gain- or loss-of transcription/secretion/function of the affected complement component. This is already known for SNPs in C3 [61,62]. (ii) Autocrine regulation of complement transcripts/secretion by complement complexes or cleavage products, which are only produced if the SNP is present, could be imaginable. Complement components or complement cleavage products can activate cellular signaling pathways via specific receptors [63-65], which can result in increased or reduced transcription of complement components by associated transcription factors [66-68]. As we showed the secretion of complement components and presents of complement activation products as well as of receptors in hpRPE cells an autocrine regulation of complement is speculatively possible.

In sum, polymorphisms within complement genes can cause different effects in AMD patients, locally in the retina and systemically.

\section{4. hpRPE Cell-Dependent Complement Activation}

Complement components can act as signal molecules by binding to their cellular receptors $[8,11]$. A pivotal requirement for complement activation is the cleavage of complement components, e.g., C3/C5, into their active, receptor-binding fragments. This can be carried out either by enzyme complexes formed by different complement proteins (convertases) or by specific proteases, e.g., cathepsin L or cathepsin B [11,69]. This results in high levels of anaphylatoxins C3a and C5a, which have been associated with physiological and pathological processes in the retina [27,70,71]: Eye morphogenesis [31], sub-RPE depositions [32], pro-inflammatory RPE reaction [33-35], PI3/Akt-pathway activation [29], and ER stress-mediated lipid accumulation [36].

Interestingly, we detected complement activation end products C3a and C5a in untreated hpRPE cells independently of the entire complement cascade. In addition, further $\mathrm{C} 3$ cleavage products C3d and C3dg were found cell-associated. Considering the absence of any external complement source, these findings indicate that complement activation occurred intracellularly, originating from autonomously produced complement protein. The production of C $3 \mathrm{a}$ and C5a has previously been described by other groups [21,26], who detected the anaphylatoxins in RPE cells following nitration of the extracellular matrix or administration of amyloid $\beta$, respectively. Activated C3b was additionally described in deposits of human fetal RPE cells cultivated without serum, indicating that a local RPE cell-associated cleavage of C3 may be efficient to excite early stages of AMD [24].

Intracellular activation of $\mathrm{C} 3$ has been assumed to be a general phenomenon, being observed in various cell types, including epithelial cell lines and murine RPE cells [11,27]. Autocrine effects of complement have initially been described in T-cells, where these processes were important to maintain the cell homeostasis $[11,72]$. Similar signaling also plays a major role in the tumor microenvironment, where it promotes tumor growth $[70,73]$. We previously suggested an autocrine function of complement components in ARPE-19 cells exposed to oxidative stress showing a colocalization of $\mathrm{C} 3$ and complement receptor 3 (CR3) [22]. Since hpRPE cells do also express the corresponding complement receptors for the autonomously produced complement activation proteins, it can be assumed that hpRPE cell can be regulated by autocrine complement-associated mechanisms, which needs to be further investigated.

\subsection{Oxidative Stress and Properdin Altered Complement and Inflammasome Associated Expression in hpRPE Cells}

AMD progresses by an interplay of genetics and cellular stress, triggered for example by oxidative stimuli [74]. We showed recently that $\mathrm{H}_{2} \mathrm{O}_{2}$ exposure of RPE cells resulted in increased levels of RPE cell-derived complement regulator properdin [22]. Properdin is the only known positive regulator of the complement system that stabilizes the C3-convertase [75,76]. Here we answered the question, how exogenous properdin can further influence the complement homeostasis of stressed hpRPE cells.

Notably, properdin treatment of stressed hpRPE cells resulted in an upregulation of CFD and CFI transcript levels, which could modulate the immune homeostasis in the retina: CFD and CFI are both proteases of the complement pathway. CFD cleaves Factor B and activates the alternative pathway, 
while CFI inactivates $\mathrm{C} 3 \mathrm{~b}$ as well as $\mathrm{C} 4 \mathrm{~b}$ [8]. In accordance with transcription data, we found also increased CFD protein concentrations in supernatants of hPRPE cells $4 \mathrm{~h}$ after properdin treatment. However, the levels of secreted CFI were decreased after properdin treatment, which was contradictory compared to the CFI mRNA levels and suggested an intracellular storage of CFI mRNA or protein in properdin-treated hpRPE cells. Intracellular storage of complement components in epithelial cells was previously associated with protection against cell death mechanisms [77].

Opposing to an upregulation of CFI and CFD mRNA expression after properdin treatment, we detected a reduction of complement transcripts $C 1 Q$ and $C 3$ as well as complement receptors $C 3 A R$, C5AR1 and CD11B. Interestingly, C3 expression was shown to be upregulated in oxidatively stressed iPSC-derived RPE and ARPE-19 cells [36,78] and previous work of our group demonstrated C5AR1 and CD11B upregulation in oxidatively stressed ARPE-19 cells [22]. This suggested a properdin-mediated contra regulation of complement transcription in oxidatively stressed hpRPE cells.

In line with this, we found a reconstitutional effect of properdin treatment in stressed hpRPE cells associated with inflammasome-linked transcripts. There are different opinions about the role of NLRP3 inflammasome in RPE cells homeostasis [79,80], but certainly NLRP3 has a pro-inflammatory effect. In line with that, there is an upregulation of NLRP3 and IL1B mRNA in oxidative stressed RPE cells, as we and others described in the past [22,81]. The additional exogenous properdin caused a $N L R P 3$ and IL1B mRNA reduction after $4 \mathrm{~h}$. This suggested a time-dependent regulative mechanism with an early anti-inflammatory effect of properdin.

\subsection{Time-Dependent Shift in Complement Gene Expression Levels Following Properdin Treatment of Stressed $h p R P E$}

When treating $\mathrm{H}_{2} \mathrm{O}_{2}$-stressed hpRPE with exogenous properdin, early complement component mRNA expression differed from late expression. Similarly, we showed earlier that oxidative stress conditions in mouse RPE lead also to a time-dependent regulation of complement component expression [82].

Of note, in our present study transcription levels of properdin-treated cells were always reversed after $24 \mathrm{~h}$ compared to $4 \mathrm{~h}$. Our assumption of a tightly regulated time-dependent complement expression profile in the RPE and retina was further supported by others showing that complement inhibiting components peaked simultaneously with photoreceptor apoptosis after light-induced retinal damage in rats [83]. A similar effect was observed for expression of AMD-related genes and cytokines in mice after intravenous sodium iodate injection [84].

Our data indicate a time-dependent early anti-inflammatory and late pro-inflammatory response of stressed hpRPE following properdin treatment. Our findings suggest that hpRPE cells are capable to autonomously counter regulate the effects of properdin exposure. All transcript analyses in this study were performed on hpRPE cells without an AMD-associated SNP within complement genes (donors 1-4) which suggested that healthy cells can circumvent external properdin stress. However, it is not yet known, how RPE cells that are positive for a SNP within complement genes can handle properdin stress, maybe counter regulation is not possible or exuberant. This needs to be further investigated in the future.

In the meanwhile clinical studies already indicate a potent impact of anti-Properdin antibodies in AMD patients: Intravitreal injection of $10 \mathrm{mg}$ anti-Properdin antibodies reduced the lesion size in GA patients by $\sim 16 \%$ compared to sham treated patients in phase 2 studies (not yet significant, NCT02515942). It seems to be a dose dependent reaction as a combination therapy of $5 \mathrm{mg}$ anti-properdin and $5 \mathrm{mg}$ anti-C5 antibodies failed to reduce lesion extension compared to the sham group (NCT02515942). However, irrespective if an anti-properdin antibody shows an effect on AMD progression in the present study, anti-properdin therapies offer the great advantage that they do not completely block the complement pathway, but instead slow down this pivotal cascade by retaining the balance of the local complement system. 


\section{Conclusions}

Our results suggested that SNPs within the complement system may contribute to RPE cell-dependent local complement production in the human eye. Complement activation observed at the RPE cell layer did not rely on systemic complement components but could be modulated by external stimuli. Properdin, the only known positive regulator of the complement system, ameliorated the effects of oxidative stress-induced complement expression in early phases and increased pro-inflammatory markers in late treatment phases.

In view of the limited sample size of hpRPE cells in this study, further studies with larger cohorts from different human donor eyes are warranted to confirm the role of genotype-dependent complement production of RPE cells. Further work is also needed to distinguish the exact role of intracellular or cell-associated and blood-derived complement as well as complement activation in the retina/RPE in the development of chronic inflammatory retinal diseases such as AMD.

Supplementary Materials: The following are available online at http://www.mdpi.com/2076-3921/9/9/793/s1, Figure S1: Ex vivo cultivated human hpRPE cells were pigmented and vital for 14 days on transwell filters, Figure S2: Western Blots of C3a and C5a in hpRPE cells, Figure S3: Complement component secretion is different in hpRPE cells from left and right donor eyes, Table S1: In-house designed RT-qPCR and PCR primers, Table S2: QuantiTect PrimerAssays (Qiagen).

Author Contributions: Conceptualization, N.S., V.E. and D.P.; Data curation, N.S., H.N.W., A.E., J.S., M.R., V.E. and D.P.; Funding acquisition, V.E. and D.P.; Investigation, N.S., H.N.W., A.E., M.R., V.E. and D.P.; Methodology, N.S., H.N.W., A.E., J.S., M.R., V.E. and D.P.; Project administration, V.E. and D.P.; Supervision, V.E. and D.P.; Visualization, N.S., A.E. and D.P.; Writing-original draft, H.N.W., A.E., M.R. and D.P.; Writing-review and editing, N.S., H.N.W., A.E., V.E. and D.P. All authors have read and agreed to the published version of the manuscript.

Funding: This research was funded by the Velux Foundation (Proj. Nr. 1103) to V.E. and D.P.

Acknowledgments: We thank Renate Föckler and Stephanie Lötscher for excellent technical support.

Conflicts of Interest: The authors declare no conflict of interest.

\section{References}

1. Edwards, A.O. Complement Factor H Polymorphism and Age-Related Macular Degeneration. Science 2005, 308, 421-424. [CrossRef] [PubMed]

2. Rivera, A.; Fisher, S.A.; Fritsche, L.G.; Keilhauer, C.N.; Lichtner, P.; Meitinger, T.; Weber, B.H.F. Hypothetical LOC387715 is a second major susceptibility gene for age-related macular degeneration, contributing independently of complement factor $\mathrm{H}$ to disease risk. Hum. Mol. Genet. 2005, 14, 3227-3236. [CrossRef] [PubMed]

3. Chrzanowska, M.; Modrzejewska, A.; Modrzejewska, M. New insight into the role of the complement in the most common types of retinopathy-current literature review. Int. J. Ophthalmol. 2018, 11, 1856-1864. [PubMed]

4. Fritsche, L.G.; Igl, W.; Bailey, J.N.C.; Grassmann, F.; Sengupta, S.; Bragg-Gresham, J.L.; Burdon, K.P.; Hebbring, S.J.; Wen, C.; Gorski, M.; et al. A large genome-wide association study of age-related macular degeneration highlights contributions of rare and common variants. Nat. Genet. 2016, 48, 134-143. [CrossRef]

5. Bonilha, V.L.; Bell, B.A.; Hu, J.; Milliner, C.; Pauer, G.J.; Hagstrom, S.A.; Radu, R.A.; Hollyfield, J.G. Geographic Atrophy: Confocal Scanning Laser Ophthalmoscopy, Histology, and Inflammation in the Region of Expanding Lesions. Investig. Ophthalmol. Vis. Sci. 2020, 61, 15. [CrossRef]

6. Whitmore, S.S.; Sohn, E.H.; Chirco, K.R.; Drack, A.V.; Stone, E.M.; Tucker, B.A.; Mullins, R.F. Complement activation and choriocapillaris loss in early AMD: Implications for pathophysiology and therapy. Prog. Retin. Eye Res. 2015, 45, 1-29. [CrossRef]

7. Kemper, C.; Atkinson, J.P.; Hourcade, D.E. Properdin: Emerging roles of a pattern-recognition molecule. Annu. Rev. Immunol. 2010, 28, 131-155. [CrossRef]

8. Merle, N.S.; Church, S.E.; Fremeaux-Bacchi, V.; Roumenina, L.T. Complement System Part I-Molecular Mechanisms of Activation and Regulation. Front. Immunol. 2015, 6, 262. [CrossRef]

9. Ghebrehiwet, B. Complement proteins in unexpected places: Why we should be excited, not concerned! F1000Res. 2020, 9. [CrossRef] 
10. King, B.C.; Renström, E.; Blom, A.M. Intracellular cytosolic complement component C3 regulates cytoprotective autophagy in pancreatic beta cells by interaction with ATG16L1. Autophagy 2019, 15, 919-921. [CrossRef]

11. Liszewski, M.K.; Kolev, M.; Le Friec, G.; Leung, M.; Bertram, P.G.; Fara, A.F.; Subias, M.; Pickering, M.C.; Drouet, C.; Meri, S.; et al. Intracellular complement activation sustains T cell homeostasis and mediates effector differentiation. Immunity 2013, 39, 1143-1157. [CrossRef]

12. Hess, C.; Kemper, C. Complement-Mediated Regulation of Metabolism and Basic Cellular Processes. Immunity 2016, 45, 240-254. [CrossRef]

13. West, E.E.; Kunz, N.; Kemper, C. Complement and human T cell metabolism: Location, location, location. Immunol. Rev. 2020, 295, 68-81. [CrossRef]

14. Viret, C.; Rozières, A.; Duclaux-Loras, R.; Boschetti, G.; Nancey, S.; Faure, M. Regulation of anti-microbial autophagy by factors of the complement system. Microb. Cell Fact. 2020, 7, 93-105. [CrossRef]

15. Chakravarthy, U.; Bailey, C.C.; Scanlon, P.H.; McKibbin, M.; Khan, R.S.; Mahmood, S.; Downey, L.; Dhingra, N.; Brand, C.; Brittain, C.J.; et al. Progression from Early/Intermediate to Advanced Forms of Age-Related Macular Degeneration in a Large UK Cohort: Rates and Risk Factors. Ophthalmol. Retin. 2020, 4, $662-672$. [CrossRef]

16. Holekamp, N.; Wykoff, C.C.; Schmitz-Valckenberg, S.; Monés, J.; Souied, E.H.; Lin, H.; Rabena, M.D.; Cantrell, R.A.; Henry, E.C.; Tang, F.; et al. Natural History of Geographic Atrophy Secondary to Age-Related Macular Degeneration: Results from the Prospective Proxima A and B Clinical Trials. Ophthalmology 2020, 127, 769-783. [CrossRef]

17. Weber, B.H.F.; Issa, P.C.; Pauly, D.; Herrmann, P.; Grassmann, F.; Holz, F.G. The role of the complement system in age-related macular degeneration. Dtsch. Arztebl. Int. 2014, 111, 133-138. [CrossRef]

18. Pujol-Lereis, L.M.; Schäfer, N.; Kuhn, L.B.; Rohrer, B.; Pauly, D. Interrelation between Oxidative Stress and Complement Activation in Models of Age-Related Macular Degeneration. Adv. Exp. Med. Biol. 2016, 854, 87-93.

19. Lakkaraju, A.; Umapathy, A.; Tan, L.X.; Daniele, L.; Philp, N.J.; Boesze-Battaglia, K.; Williams, D.S. The cell biology of the retinal pigment epithelium. Prog. Retin. Eye Res. 2020, 100846. [CrossRef]

20. Mohlin, C.; Sandholm, K.; Kvanta, A.; Ekdahl, K.N.; Johansson, K. A model to study complement involvement in experimental retinal degeneration. Ups. J. Med. Sci. 2018, 123, 28-42. [CrossRef]

21. Wu, L.; Tan, X.; Liang, L.; Yu, H.; Wang, C.; Zhang, D.; Kijlstra, A.; Yang, P. The Role of Mitochondria-Associated Reactive Oxygen Species in the Amyloid $\beta$ Induced Production of Angiogenic Factors by ARPE-19 Cells. Curr. Mol. Med. 2017, 17, 140-148. [CrossRef]

22. Trakkides, T.-O.; Schäfer, N.; Reichenthaler, M.; Kühn, K.; Brandwijk, R.J.; Toonen, E.J.M.; Urban, F.; Wegener, J.; Enzmann, V.; Pauly, D. Oxidative Stress Increases Endogenous Complement-Dependent Inflammatory and Angiogenic Responses in Retinal Pigment Epithelial Cells Independently of Exogenous Complement Sources. Antioxidants 2019, 8, 548. [CrossRef]

23. Sugita, S.; Makabe, K.; Fujii, S.; Takahashi, M. Detection of Complement Activators in Immune Attack Eyes After iPS-Derived Retinal Pigment Epithelial Cell Transplantation. Investig. Ophthalmol. Vis. Sci. 2018, 59, 4198-4209. [CrossRef]

24. Fernandez-Godino, R.; Bujakowska, K.M.; Pierce, E.A. Changes in extracellular matrix cause RPE cells to make basal deposits and activate the alternative complement pathway. Hum. Mol. Genet. 2018, 27, 147-159. [CrossRef]

25. Hwang, N.; Chung, S.W. Sulfasalazine attenuates tamoxifen-induced toxicity in human retinal pigment epithelial cells. BMB Rep. 2020, 53, 284-289. [CrossRef]

26. Fields, M.A.; Bowrey, H.E.; Gong, J.; Moreira, E.F.; Cai, H.; Del Priore, L.V. Extracellular matrix nitration alters growth factor release and activates bioactive complement in human retinal pigment epithelial cells. PLoS ONE 2017, 12, e0177763. [CrossRef]

27. Kaur, G.; Tan, L.X.; Rathnasamy, G.; La Cunza, N.; Germer, C.J.; Toops, K.A.; Fernandes, M.; Blenkinsop, T.A.; Lakkaraju, A. Aberrant early endosome biogenesis mediates complement activation in the retinal pigment epithelium in models of macular degeneration. Proc. Natl. Acad. Sci. USA 2018, 115, 9014-9019. [CrossRef]

28. Armento, A.; Honisch, S.; Panagiotakopoulou, V.; Sonntag, I.; Jacob, A.; Bolz, S.; Kilger, E.; Deleidi, M.; Clark, S.; Ueffing, M. Loss of Complement Factor H impairs antioxidant capacity and energy metabolism of human RPE cells. Sci. Rep. 2020, 10, 10320. [CrossRef] 
29. Busch, C.; Annamalai, B.; Abdusalamova, K.; Reichhart, N.; Huber, C.; Lin, Y.; Jo, E.A.H.; Zipfel, P.F.; Skerka, C.; Wildner, G.; et al. Anaphylatoxins Activate Ca, Akt/PI3-Kinase, and FOXO1/FoxP3 in the Retinal Pigment Epithelium. Front. Immunol. 2017, 8, 703. [CrossRef]

30. Brandstetter, C.; Patt, J.; Holz, F.G.; Krohne, T.U. Inflammasome priming increases retinal pigment epithelial cell susceptibility to lipofuscin phototoxicity by changing the cell death mechanism from apoptosis to pyroptosis. J. Photochem. Photobiol. B 2016, 161, 177-183. [CrossRef]

31. Grajales-Esquivel, E.; Luz-Madrigal, A.; Bierly, J.; Haynes, T.; Reis, E.S.; Han, Z.; Gutierrez, C.; McKinney, Z.; Tzekou, A.; Lambris, J.D.; et al. Complement component $C 3 a R$ constitutes a novel regulator for chick eye morphogenesis. Dev. Biol. 2017, 428, 88-100. [CrossRef] [PubMed]

32. Fernandez-Godino, R.; Pierce, E.A. C3a triggers formation of sub-retinal pigment epithelium deposits via the ubiquitin proteasome pathway. Sci. Rep. 2018, 8, 9679. [CrossRef] [PubMed]

33. Wang, L.; Cano, M.; Datta, S.; Wei, H.; Ebrahimi, K.B.; Gorashi, Y.; Garlanda, C.; Handa, J.T. Pentraxin 3 recruits complement factor $\mathrm{H}$ to protect against oxidative stress-induced complement and inflammasome overactivation. J. Pathol. 2016, 240, 495-506. [CrossRef] [PubMed]

34. Wang, L.; Kondo, N.; Cano, M.; Ebrahimi, K.; Yoshida, T.; Barnett, B.P.; Biswal, S.; Handa, J.T. Nrf2 signaling modulates cigarette smoke-induced complement activation in retinal pigmented epithelial cells. Free Radic. Biol. Med. 2014, 70, 155-166. [CrossRef]

35. Brandstetter, C.; Holz, F.G.; Krohne, T.U. Complement Component C5a Primes Retinal Pigment Epithelial Cells for Inflammasome Activation by Lipofuscin-mediated Photooxidative Damage. J. Biol. Chem. 2015, 290, 31189-31198. [CrossRef]

36. Kunchithapautham, K.; Atkinson, C.; Rohrer, B. Smoke exposure causes endoplasmic reticulum stress and lipid accumulation in retinal pigment epithelium through oxidative stress and complement activation. J. Biol. Chem. 2014, 289, 14534-14546. [CrossRef]

37. Blenkinsop, T.A.; Salero, E.; Stern, J.H.; Temple, S. The culture and maintenance of functional retinal pigment epithelial monolayers from adult human eye. Methods Mol. Biol. 2013, 945, 45-65.

38. Parisi, L.; Fuhrer, R.; Zinkernagel, M.; Enzmann, V. Ranibizumab and Bevacizumab but Not Aflibercept Inhibit Proliferation of Primary Human Retinal Pigment Epithelium in vitro. Ophthalmologica 2019, 241, 137-142. [CrossRef]

39. Bustin, S.A.; Benes, V.; Garson, J.A.; Hellemans, J.; Huggett, J.; Kubista, M.; Mueller, R.; Nolan, T.; Pfaffl, M.W.; Shipley, G.L.; et al. The MIQE guidelines: Minimum information for publication of quantitative real-time PCR experiments. Clin. Chem. 2009, 55, 611-622. [CrossRef]

40. Livak, K.J.; Schmittgen, T.D. Analysis of relative gene expression data using real-time quantitative PCR and the 2(-Delta Delta C(T)) Method. Methods 2001, 25, 402-408. [CrossRef]

41. Quackenbush, J. Microarray data normalization and transformation. Nat. Genet. 2002, 32, 496-501. [CrossRef] [PubMed]

42. Pauly, D.; Agarwal, D.; Dana, N.; Schäfer, N.; Biber, J.; Wunderlich, K.A.; Jabri, Y.; Straub, T.; Zhang, N.R.; Gautam, A.K.; et al. Cell-Type-Specific Complement Expression in the Healthy and Diseased Retina. Cell Rep. 2019, 29, 2835-2848.e4. [CrossRef]

43. Mullins, R.F.; Dewald, A.D.; Streb, L.M.; Wang, K.; Kuehn, M.H.; Stone, E.M. Elevated membrane attack complex in human choroid with high risk complement factor H genotypes. Exp. Eye Res. 2011, 93, 565-567. [CrossRef] [PubMed]

44. Cao, S.; Wang, J.C.C.; Gao, J.; Wong, M.; To, E.; White, V.A.; Cui, J.Z.; Matsubara, J.A. CFH Y402H polymorphism and the complement activation product C5a: Effects on NF- $\mathrm{kB}$ activation and inflammasome gene regulation. Br. J. Ophthalmol. 2016, 100, 713-718. [CrossRef] [PubMed]

45. Ablonczy, Z.; Dahrouj, M.; Tang, P.H.; Liu, Y.; Sambamurti, K.; Marmorstein, A.D.; Crosson, C.E. Human retinal pigment epithelium cells as functional models for the RPE in vivo. Investig. Ophthalmol. Vis. Sci. 2011, 52, 8614-8620. [CrossRef]

46. Dunn, K.C.; Marmorstein, A.D.; Bonilha, V.L.; Rodriguez-Boulan, E.; Giordano, F.; Hjelmeland, L.M. Use of the ARPE-19 cell line as a model of RPE polarity: Basolateral secretion of FGF5. Investig. Ophthalmol. Vis. Sci. 1998, 39, 2744-2749. 
47. Joseph, K.; Kulik, L.; Coughlin, B.; Kunchithapautham, K.; Bandyopadhyay, M.; Thiel, S.; Thielens, N.M.; Holers, V.M.; Rohrer, B. Oxidative stress sensitizes retinal pigmented epithelial (RPE) cells to complement-mediated injury in a natural antibody-, lectin pathway-, and phospholipid epitope-dependent manner. J. Biol. Chem. 2013, 288, 12753-12765. [CrossRef]

48. Alizadeh, M.; Wada, M.; Gelfman, C.M.; Handa, J.T.; Hjelmeland, L.M. Downregulation of differentiation specific gene expression by oxidative stress in ARPE-19 cells. Investig. Ophthalmol. Vis. Sci. 2001, 42, 2706-2713.

49. Ahmado, A.; Carr, A.-J.; Vugler, A.A.; Semo, M.; Gias, C.; Lawrence, J.M.; Chen, L.L.; Chen, F.K.; Turowski, P.; da Cruz, L.; et al. Induction of differentiation by pyruvate and DMEM in the human retinal pigment epithelium cell line ARPE-19. Investig. Ophthalmol. Vis. Sci. 2011, 52, 7148-7159. [CrossRef]

50. Luo, C.; Zhao, J.; Madden, A.; Chen, M.; Xu, H. Complement expression in retinal pigment epithelial cells is modulated by activated macrophages. Exp. Eye Res. 2013, 112, 93-101. [CrossRef]

51. Weinberger, A.W.A.; Eddahabi, C.; Carstesen, D.; Zipfel, P.F.; Walter, P.; Skerka, C. Human complement factor $\mathrm{H}$ and factor $\mathrm{H}$-like protein 1 are expressed in human retinal pigment epithelial cells. Ophthalmic Res. 2014, 51,59-66. [CrossRef] [PubMed]

52. Cowan, C.S.; Renner, M.; Gross-Scherf, B.; Goldblum, D.; Munz, M.; Krol, J.; Szikra, T.; Papasaikas, P.; Cuttat, R.; Waldt, A.; et al. Cell types of the human retina and its organoids at single-cell resolution: Developmental convergence, transcriptomic identity, and disease map. SSRN Electron. J. 2019. [CrossRef]

53. Andoh, A.; Fujiyama, Y.; Bamba, T.; Hosoda, S. Differential cytokine regulation of complement C3, C4, and factor B synthesis in human intestinal epithelial cell line, Caco-2. J. Immunol. 1993, 151, 4239-4247. [PubMed]

54. Li, X.; Ding, F.; Zhang, X.; Li, B.; Ding, J. The Expression Profile of Complement Components in Podocytes. Int. J. Mol. Sci. 2016, 17, 471. [CrossRef] [PubMed]

55. Waldstein, S.M.; Vogl, W.-D.; Bogunovic, H.; Sadeghipour, A.; Riedl, S.; Schmidt-Erfurth, U. Characterization of Drusen and Hyperreflective Foci as Biomarkers for Disease Progression in Age-Related Macular Degeneration Using Artificial Intelligence in Optical Coherence Tomography. JAMA Ophthalmol. 2020. [CrossRef]

56. Govetto, A.; Sarraf, D.; Figueroa, M.S.; Pierro, L.; Ippolito, M.; Risser, G.; Bandello, F.; Hubschman, J.P. Choroidal thickness in non-neovascular versus neovascular age-related macular degeneration: A fellow eye comparative study. Br. J. Ophthalmol. 2017, 101, 764-769. [CrossRef]

57. Grassmann, F.; Fritsche, L.G.; Keilhauer, C.N.; Heid, I.M.; Weber, B.H.F. Modelling the genetic risk in age-related macular degeneration. PLoS ONE 2012, 7, e37979. [CrossRef]

58. Fritsche, L.G.; Chen, W.; Schu, M.; Yaspan, B.L.; Yu, Y.; Thorleifsson, G.; Zack, D.J.; Arakawa, S.; Cipriani, V.; Ripke, S.; et al. Seven new loci associated with age-related macular degeneration. Nat. Genet. 2013, 45, 433-439.

59. Micklisch, S.; Lin, Y.; Jacob, S.; Karlstetter, M.; Dannhausen, K.; Dasari, P.; von der Heide, M.; Dahse, H.-M.; Schmölz, L.; Grassmann, F.; et al. Age-related macular degeneration associated polymorphism rs10490924 in ARMS2 results in deficiency of a complement activator. J. Neuroinflamm. 2017, 14, 4. [CrossRef]

60. Hallam, T.M.; Marchbank, K.J.; Harris, C.L.; Osmond, C.; Shuttleworth, V.G.; Griffiths, H.; Cree, A.J.; Kavanagh, D.; Lotery, A.J. Rare Genetic Variants in Complement Factor I Lead to Low FI Plasma Levels Resulting in Increased Risk of Age-Related Macular Degeneration. Investig. Ophthalmol. Vis. Sci. 2020, 61, 18. [CrossRef]

61. Lhotta, K.; Janecke, A.R.; Scheiring, J.; Petzlberger, B.; Giner, T.; Fally, V.; Würzner, R.; Zimmerhackl, L.B.; Mayer, G.; Fremeaux-Bacchi, V. A large family with a gain-of-function mutation of complement C3 predisposing to atypical hemolytic uremic syndrome, microhematuria, hypertension and chronic renal failure. Clin. J. Am. Soc. Nephrol. 2009, 4, 1356-1362. [CrossRef] [PubMed]

62. Singer, L.; Whitehead, W.T.; Akama, H.; Katz, Y.; Fishelson, Z.; Wetsel, R.A. Inherited human complement C3 deficiency. An amino acid substitution in the beta-chain (ASP549 to ASN) impairs C3 secretion. J. Biol. Chem. 1994, 269, 28494-28499. [PubMed]

63. Li, L.; Chen, L.; Zang, J.; Tang, X.; Liu, Y.; Zhang, J.; Bai, L.; Yin, Q.; Lu, Y.; Cheng, J.; et al. C3a and C5a receptor antagonists ameliorate endothelial-myofibroblast transition via the $\mathrm{Wnt} / \beta$-catenin signaling pathway in diabetic kidney disease. Metabolism 2015, 64, 597-610. [CrossRef] 
64. Naito, A.T.; Sumida, T.; Nomura, S.; Liu, M.-L.; Higo, T.; Nakagawa, A.; Okada, K.; Sakai, T.; Hashimoto, A.; Hara, Y.; et al. Complement C1q activates canonical Wnt signaling and promotes aging-related phenotypes. Cell 2012, 149, 1298-1313. [CrossRef]

65. Yuan, K.; Ye, J.; Liu, Z.; Ren, Y.; He, W.; Xu, J.; He, Y.; Yuan, Y. Complement C3 overexpression activates JAK2/STAT3 pathway and correlates with gastric cancer progression. J. Exp. Clin. Cancer Res. 2020, 39, 9. [CrossRef]

66. Xiong, S.; Yu, Y.; Zhou, X.; Xia, X.; Jiang, H. Rhodopsin T17M Mutant Inhibits Complement C3 Secretion in Retinal Pigment Epithelium via ROS Induced Downregulation of TWIST1. J. Cell. Biochem. 2017, 118, 4914-4920. [CrossRef]

67. Cho, M.S.; Rupaimoole, R.; Choi,H.-J.; Noh, K.; Chen, J.; Hu, Q.; Sood, A.K.; Afshar-Kharghan, V. Complement Component 3 Is Regulated by TWIST1 and Mediates Epithelial-Mesenchymal Transition. J. Immunol. 2016, 196, 1412-1418. [CrossRef]

68. Camporeale, A.; Marino, F.; Papageorgiou, A.; Carai, P.; Fornero, S.; Fletcher, S.; Page, B.D.; Gunning, P.; Forni, M.; Chiarle, R.; et al. STAT3 activity is necessary and sufficient for the development of immune-mediated myocarditis in mice and promotes progression to dilated cardiomyopathy. EMBO Mol. Med. 2013, 5, 572-590. [CrossRef]

69. Huber-Lang, M.; Sarma, J.V.; Zetoune, F.S.; Rittirsch, D.; Neff, T.A.; McGuire, S.R.; Lambris, J.D.; Warner, R.L.; Flierl, M.A.; Hoesel, L.M.; et al. Generation of C5a in the absence of C3: A new complement activation pathway. Nat. Med. 2006, 12, 682-687. [CrossRef]

70. Corrales, L.; Ajona, D.; Rafail, S.; Lasarte, J.J.; Riezu-Boj, J.I.; Lambris, J.D.; Rouzaut, A.; Pajares, M.J.; Montuenga, L.M.; Pio, R. Anaphylatoxin C5a creates a favorable microenvironment for lung cancer progression. J. Immunol. 2012, 189, 4674-4683. [CrossRef]

71. Heesterbeek, T.J.; Lechanteur, Y.T.E.; Lorés-Motta, L.; Schick, T.; Daha, M.R.; Altay, L.; Liakopoulos, S.; Smailhodzic, D.; den Hollander, A.I.; Hoyng, C.B.; et al. Complement Activation Levels Are Related to Disease Stage in AMD. Investig. Ophthalmol. Vis. Sci. 2020, 61, 18. [CrossRef] [PubMed]

72. Strainic, M.G.; Liu, J.; Huang, D.; An, F.; Lalli, P.N.; Muqim, N.; Shapiro, V.S.; Dubyak, G.R.; Heeger, P.S.; Medof, M.E. Locally produced complement fragments C5a and C3a provide both costimulatory and survival signals to naive CD4+ T cells. Immunity 2008, 28, 425-435. [CrossRef] [PubMed]

73. Cho, M.S.; Vasquez, H.G.; Rupaimoole, R.; Pradeep, S.; Wu, S.; Zand, B.; Han, H.-D.; Rodriguez-Aguayo, C.; Bottsford-Miller, J.; Huang, J.; et al. Autocrine effects of tumor-derived complement. Cell Rep. 2014, 6, 1085-1095. [CrossRef] [PubMed]

74. Thurman, J.M.; Renner, B.; Kunchithapautham, K.; Ferreira, V.P.; Pangburn, M.K.; Ablonczy, Z.; Tomlinson, S.; Holers, V.M.; Rohrer, B. Oxidative stress renders retinal pigment epithelial cells susceptible to complement-mediated injury. J. Biol. Chem. 2009, 284, 16939-16947. [CrossRef] [PubMed]

75. Chen, J.Y.; Cortes, C.; Ferreira, V.P. Properdin: A multifaceted molecule involved in inflammation and diseases. Mol. Immunol. 2018, 102, 58-72. [CrossRef]

76. Alcorlo, M.; Tortajada, A.; Rodríguez de Córdoba, S.; Llorca, O. Structural basis for the stabilization of the complement alternative pathway C3 convertase by properdin. Proc. Natl. Acad. Sci. USA 2013, 110, 13504-13509. [CrossRef]

77. Kulkarni, H.S.; Elvington, M.L.; Perng, Y.-C.; Liszewski, M.K.; Byers, D.E.; Farkouh, C.; Yusen, R.D.; Lenschow, D.J.; Brody, S.L.; Atkinson, J.P. Intracellular C3 Protects Human Airway Epithelial Cells from Stress-associated Cell Death. Am. J. Respir. Cell Mol. Biol. 2019, 60, 144-157. [CrossRef]

78. Fanelli, G.; Gonzalez-Cordero, A.; Gardner, P.J.; Peng, Q.; Fernando, M.; Kloc, M.; Farrar, C.A.; Naeem, A.; Garred, P.; Ali, R.R.; et al. Human stem cell-derived retinal epithelial cells activate complement via collectin 11 in response to stress. Sci. Rep. 2017, 7, 14625. [CrossRef]

79. Wooff, Y.; Fernando, N.; Wong, J.H.C.; Dietrich, C.; Aggio-Bruce, R.; Chu-Tan, J.A.; Robertson, A.A.B.; Doyle, S.L.; Man, S.M.; Natoli, R. Caspase-1-dependent inflammasomes mediate photoreceptor cell death in photo-oxidative damage-induced retinal degeneration. Sci. Rep. 2020, 10, 2263. [CrossRef]

80. Kosmidou, C.; Efstathiou, N.E.; Hoang, M.V.; Notomi, S.; Konstantinou, E.K.; Hirano, M.; Takahashi, K.; Maidana, D.E.; Tsoka, P.; Young, L.; et al. Issues with the Specificity of Immunological Reagents for NLRP3: Implications for Age-related Macular Degeneration. Sci. Rep. 2018, 8, 461. [CrossRef] 
81. Wang, Y.; Hanus, J.W.; Abu-Asab, M.S.; Shen, D.; Ogilvy, A.; Ou, J.; Chu, X.K.; Shi, G.; Li, W.; Wang, S.; et al. NLRP3 Upregulation in Retinal Pigment Epithelium in Age-Related Macular Degeneration. Int. J. Mol. Sci. 2016, 17, 73. [CrossRef] [PubMed]

82. Schäfer, N.; Grosche, A.; Schmitt, S.I.; Braunger, B.M.; Pauly, D. Complement Components Showed a Time-Dependent Local Expression Pattern in Constant and Acute White Light-Induced Photoreceptor Damage. Front. Mol. Neurosci. 2017, 10, 197. [CrossRef] [PubMed]

83. Rutar, M.; Natoli, R.; Kozulin, P.; Valter, K.; Gatenby, P.; Provis, J.M. Analysis of complement expression in light-induced retinal degeneration: Synthesis and deposition of C3 by microglia/macrophages is associated with focal photoreceptor degeneration. Investig. Ophthalmol. Vis. Sci. 2011, 52, 5347-5358. [CrossRef] [PubMed]

84. Moriguchi, M.; Nakamura, S.; Inoue, Y.; Nishinaka, A.; Nakamura, M.; Shimazawa, M.; Hara, H. Irreversible Photoreceptors and RPE Cells Damage by Intravenous Sodium Iodate in Mice Is Related to Macrophage Accumulation. Investig. Ophthalmol. Vis. Sci. 2018, 59, 3476-3487. [CrossRef]

(C) 2020 by the authors. Licensee MDPI, Basel, Switzerland. This article is an open access article distributed under the terms and conditions of the Creative Commons Attribution (CC BY) license (http://creativecommons.org/licenses/by/4.0/). 